\title{
CHAPTER 3: Contested Spaces, New Opportunities: Displacement, Return and the Rural Economy in Casamance, Senegal
}

(Published 2014 in Hammar, A. (ed.) Displacement economies: paradoxes of crisis and creativity in African contexts: 57-78. London: Zed Books.)

\section{MARTIN EVANS ${ }^{1}$}

\section{Introduction}

Casamance is the southwesternmost part of Senegal, largely separated from the rest of the country by The Gambia to the north and bordering Guinea-Bissau to the south. As the scene of West Africa's longestrunning civil conflict, now some 30 years old, Casamance provides a case of displacement economies on a relatively small scale but of long duration. The focus here is on human displacement, understood as the enforced physical dislocation of people, the dynamics of their return and resettlement, and the economic, political and social effects related to these processes. Much of the long-term human displacement in the conflict has occurred in the relatively narrow band of territory between the south bank of the Casamance River and northern border districts of Guinea-Bissau. Following flight and protracted exile from this border area in the 1990s, however, the 2000s and beyond have mostly seen people return, driven by economic and social desperation coupled with generally improved (though still at times volatile) security conditions, and supported by international aid for reconstruction.

Building on field research conducted over twelve years, the chapter considers the emergent economic and political landscape of the border area. It shows how this landscape is the result of layers of displacement over two decades, situated within a deeper historical context of migration. From a theoretical perspective, it seeks to understand these dynamics through the concept of 'relational space', 
formulated in human geography and beginning to be used, if not always explicitly, in studies of displacement.

\section{Displacement and Relational Space}

Space matters, and at the smallest scale; but from a theoretical perspective, it is sometimes all too apparent that different disciplines talk about space in different ways. The analysis presented here takes from human geography the notion of 'relational space' in the sense of David Harvey (2005) and Doreen Massey (2005). This is space constituting and constitutive of social relationships. As Harvey explains, '[p]rocesses do not occur in space but define their own spatial frame. The concept of space is embedded in or internal to process' (2005: 273; emphasis in original). While proponents of relational space (as analytical tool) admit that it is difficult to work with, and impossible to 'map' in any Cartesian or absolute sense, they argue that it is, as social reality, the space in which all people actually operate. Massey (2005: 9) describes this

... space as the product of interrelations; as constituted through interactions, from the immensity of the global to the intimately tiny... space as always under construction. Precisely because space on this reading is a product of relations-between, relations which are necessarily embedded material practices which have to be carried out, it is always in the process of being made... Perhaps we could imagine space as a simultaneity of stories-so-far.

This highlights two further points about how the concept of relational space works in real contexts. The first is exactly that, its essential link with the real and material: relationality only begets action and meaning through the material world. Harvey underlines the dangers of conceptualizing space in tooabstruse terms; whereas '[i]t is only when relationality connects to the absolute spaces and times of social and material life that politics comes alive' (2005: 293). The second point is how the concept can help 
understand linkages between processes at different scales. Much is said about relationships between the global and the local but this is, again, often vague (Harvey 2005): linkages are presumed but real articulations between different spatial scales of social and material relations are brushed over. The risk is that 'global forces' thus become a lazy trope to explain, inadequately, what is happening locally, while local dynamics in their own right are understated or ignored.

Human displacement, as defined above, is an inherently spatial process, lending itself naturally to the idea that relational space is constantly being 'made'. Relational understandings of space are indeed increasingly applied in displacement settings even if such studies are not always explicitly framed in these terms theoretically. This approach reflects the broader, contemporary 'spatial turn' in the humanities and social sciences beyond geography and thus increasingly evident in African Studies (for example Engel \& Nugent 2010a). Two fields in which ideas akin to human-geographic conceptualizations of relationality emerge most strongly are studies of borderlands and mobility in Africa. This comes with the admission that 'social processes of bordering' (Engel \& Nugent 2010b: 4) - in a relational sense, how space is 'made' by cross-border practices - remain under-researched. Still, good examples can be found: in the Angola-Zambia borderlands, Barrett (2009) applies the notion of 'hodological space', from the Greek hodos meaning 'path', to understand the lived reality of moving between two points. The socially constructed nature of pathways in contexts of mobility (forced or voluntary) is also explored by Lindley (2009) for Somalia; and by Schapendonk (2010) for stepwise migration from sub-Saharan Africa northwards into the Maghreb and beyond. Mobility provides the focus for a recent conceptualization of cross-border space in the Sahel, too (Retaillé \& Walther 2011). Other authors explore how displaced people, specifically, use cross-border practices to their economic and social advantage, for example the Fula across the Sierra Leone/Guinea-Conakry border (Gale 2006) and the Diola across the Senegal/Gambia border (Evans \& Ray 2013). For internally displaced persons (IDPs), studies of spatial practices and their social meaning can similarly be found. The role of insecurity in shaping the spatial behaviour of displaced populations is described, for example, for child 'night commuters' in northern Uganda (Dunn 2007). Outside of Africa but certainly applicable therein, Oslender's (2008) novel 
conceptions of 'geographies of terror' and 'spaces of confinement' are applied in his study of black communities in Colombia subject to violence and displacement by state actors with economic motivations.

Another way to view the relational spaces of people affected by displacement comes from studies of land tenure, which naturally point to the very local character of such dynamics and, importantly, the ways in which people's relationships to land in Africa are ingrained in local histories (Englund 1996, 1999). Some research on the self-settled displaced in Africa - the single largest group of IDPs and refugees on the continent (UNHCR 2011) - concerns how individuals or households create habitable and productive spaces in reception areas. In a study of unusual depth, Black \& Sessay (1997) analyse land use change in parts of southeast Guinea-Conakry that received large influxes of Liberian and Sierra Leonean refugees. Highlighting the importance of local institutions and how they adapt, the authors show how land requirements from refugees were accommodated. Rather than becoming a burden on reception areas, refugees were often an asset, valorizing fallows and working existing productive land more intensively, enhancing production. Similar accommodation is seen in a few other studies, notably that of Leach (1992) on Liberian refugees in Sierra Leone; and of Black \& Sessay (1998) again, this time on Mauritanian refugees in the Senegal River Valley. If and when people go home, return and reconstruction also involve complex and very local processes: 'rebuilding' communities can in reality involve significant reconfigurations of local economic and political space compared with the pre-displacement condition. This has long been the subject of research, again focused on issues of land tenure and natural resource access, in 'post-conflict' settings in Mozambique and elsewhere (McGregor 1997 and 1998; Unruh 1998; Unruh \& Bailey 2009; Unruh et al. 2003). More recently interest in land tenure in conflict/post-conflict settings has been boosted by recognition of its importance by the humanitarian community (see for example Pantuliano 2009).

A further key aspect of relational space is the way in which external (including international) influences shape local political space in Africa, a subject on which relatively little published research exists despite the long history of such processes (Howard 2010). In an intriguing comment in his classic 
study of Haalpulaar villages in Senegal, Schmitz (1994: 429) notes how territory has been 'déstructuré' (destructured) over time by outmigration. The growing economic significance of the diaspora in remitting money for livelihoods and development in the village has rendered its relationships with its neighbours less important, making each village increasingly autonomous. In Nigeria, van den Bersselaar (2005) also observes the role of the diasporic community in shaping the spatial form of the village, a process similarly noted in neighbouring Cameroon down to sub-village level (Evans 2010). Beyond the diaspora, however, less consideration is given to the role of external forces in local politico-spatial dynamics as such. On the other hand, research has clearly shown the influence of the international development industry on local associational and community life in Africa (among others Mercer 2002; Kelsall \& Mercer 2003; Fanthorpe \& Maconachie 2010).

In sum, the close-grained studies identified, particularly from meso-level down to micro-level relationships, for example within a village - tending towards Massey's 'intimately tiny' scale - show how space is made, in a relational sense, in displacement settings in Africa. The processes involved in human

displacement are experienced by most people at a local level and play out at a local scale, albeit within larger political and economic spaces and under external, sometimes global influences. The chapter now turns to an account of the case study in question and its geographies of displacement.

\section{The Casamance Conflict}

Originally one region, Casamance today comprises three administrative regions: Ziguinchor, Sédhiou and Kolda, named for their respective capitals. Casamance was divided into Ziguinchor and Kolda regions in 1984, and Sédhiou region formed out of part of Kolda region in 2008. In popular parlance and particularly in relation to the conflict, though, 'Casamance' is still described as one territorial unit. The contemporary violence there originated in Casamançais discontent with the Senegalese administration in the 1970s and early 1980s (Evans 2004), culminating in the Mouvement des forces démocratiques de la Casamance (MFDC) demanding independence for Casamance from Senegal. The MFDC has since continued to make 
this demand on the basis of essentially the same grievances. These include poor governance from Dakar (the national capital, situated in northern Senegal), purported deliberate underdevelopment of Casamance, and high-handedness and abuses by northern Senegalese administrators and traders (referred to pejoratively as 'nordistes') operating there. The latter behaviour is related partly to cultural differences between Casamance and the north. Crucially, the separatists also make the still-disputed claim that Casamance had full political autonomy during colonial times. In their view, the incorporation of Casamance into the independent Republic of Senegal in 1960 is thereby open to legal challenge.

In 1982 and 1983, this discontent was mobilized in protest marches in Ziguinchor, capital of the then-unified Casamance region. Though largely peaceful in intent, the marches prompted increasingly oppressive and violent reactions from the Senegalese authorities. There were over 100 arrests following the first march in 1982. At the second in 1983, Senegalese forces fired on protestors with live rounds, killing between 50 and 200 people; they then pursued, arrested and harassed many other marchers and their associates. These actions drove the MFDC underground and, faced with ongoing government oppression and seeing no political solution, it procured firearms and launched an insurgency against Senegalese forces in Casamance in 1990. The deployment of the Senegalese army in response led to fullscale militarization of the conflict. The consequences have included an estimated 3,000-5,000 combatrelated deaths, human rights abuses by both sides, and displacement of more than 60,000 people, the majority as IDPs and others as refugees in The Gambia or Guinea-Bissau. The latter country, particularly, has also hosted rear bases for MFDC guerrillas. The conflict has brought severe livelihood problems to many Casamançais as important economic sectors (agriculture, fishing and tourism) have been damaged by the conflict, indeed sometimes deliberately targeted, while foreign aid and investment have at times been withdrawn.

From late 2000 security conditions in Casamance generally improved and continued to do so for much of the following decade. The reasons include greater cooperation from Guinea-Bissau with Senegal vis-à-vis hardline MFDC guerrillas using the former country's territory; re-established if deeply troubled negotiations; exhaustion among the guerrillas; and a huge grassroots desire for peace among 
Casamançais. However, progress in resolving the conflict as such has proved elusive. The most recent accord between elements of the MFDC and the Senegalese government was signed in December 2004, although this was arguably a public relations exercise to encourage further donor aid while masking structural problems in the peace process. Negotiations between the government and multiple MFDC elements, envisaged in the 2004 accord, stalled after initial talks in 2005. Only piecemeal contacts continued between the government, in the person of President Abdoulaye Wade or his emissaries, and self-appointed interlocutors for particular MFDC factions. The election of Macky Sall to the Senegalese Presidency in March 2012 has brought a different approach to the conflict but it remains to be seen to what extent this translates into changes on the ground. In the meantime, the 2004 accord has not brought a sustainable peace, much like other failed ceasefires and agreements in the 1990s, and sporadic violence continues at the time of writing.

\section{Geographies of Displacement in the Guinea-Bissau Border Zone}

Most of Ziguinchor region, the westernmost part of Casamance and original epicentre of the rebellion, has been affected by the conflict in some way, and from the mid-1990s onwards the violence spread eastward into areas of what is now Sédhiou region. There have, broadly speaking, been marked differences between the dynamics north and south of the Casamance River. In the 1990s, districts south of the Riverthe focus of the chapter - were most heavily affected by violence and displacement, particularly rural areas along the Guinea-Bissau border and extending to outer suburbs and satellite villages of Ziguinchor, situated on the River's south bank (Evans 2005 and 2007). Much of this violence was perpetrated by MFDC guerrillas of the Front Sud acting from their rear bases in Guinea-Bissau, with various motives. First, they aimed to extend their territorial control into Casamance for political purposes and to be in a stronger position to attack Senegalese forces. Second, violence was used as a terror tactic against civilians who refused to participate in or otherwise support the rebellion. And third, it was used for economic purposes: while not a primary motivation, emptying villages of their populations enabled guerrillas to 
take the belongings and livestock of the displaced, and in the longer term to harvest their orchard crops, all of which they could consume, sell or exchange to support their livelihoods and war effort (Evans 2003a). By contrast, north of the Casamance River, again in Ziguinchor region and certain neighbouring parts of Sédhiou region, a different but no less troubled history has unfolded. This is not considered here beyond noting that violence in the area in the 2000s and into the 2010s has periodically displaced rural people into The Gambia. This physical dislocation has mostly been temporary in character although recent years have seen a trend towards more permanent settlement by refugees (Evans \& Ray 2013).

Long-term human displacement in Casamance shows various characteristics (Evans 2007). First, in terms of scale, any figures can only be approximate but a census carried out in 1998 by Caritas gave a total of over 62,000 IDPs and refugees. Figures specifically for refugees (in Guinea-Bissau and The Gambia) have tended to gravitate around 10,000, indicating that most displacement has been internal. Second, displacement has shown a clear spatial concentration related to the geography of the conflict. Ziguinchor region (unsurprisingly as the main area affected by violence) accounts for around $70 \%$ of the Caritas figure, but the great majority of this (63\% of the total) is in Ziguinchor department, ${ }^{2}$ lying between the Casamance River and the Guinea-Bissau border in southeastern Ziguinchor region. Most of the remaining $30 \%$ has been displaced from the contiguous part of the Guinea-Bissau border area in what is now Sédhiou region. Other data indicate that displacement in the border area, while it took place over a number of years, was mostly the result of a few events that displaced people (often whole village populations) en masse. Fighting that took place in 1992 may alone have displaced tens of thousands. For example one rural community ${ }^{3}$ in Ziguinchor department ultimately saw some $60 \%$ of its total population of 7,000 displaced, mostly in that one year (Evans 2007).

A third important feature of displacement in Casamance is that people have often only moved short distances: into larger towns along the south bank of the River, across borders into neighbouring areas of Guinea-Bissau and The Gambia, or even into the more secure cores of villages from peripheral quarters (Evans 2005, 2007). Many refugees in The Gambia, in particular, situate themselves sufficiently close to their home areas so that they can 'commute' across the border to maintain farms and social 
relations in Casamance (Evans \& Ray 2013). Fourth, while reception centres and camps have received IDPs and refugees, the vast majority of those displaced in Casamance have self-settled, often with kinsfolk at least in the first instance (Evans 2007; Evans \& Ray 2013). Overall, then, the dynamics of displacement reflect the confined area in which the conflict has unfolded, its complex local geographies, and the social relations of those affected within Casamance and across its borders (Evans 2003b; Foucher 2007).

These geographies continue to evolve. The Guinea-Bissau border zone was generally calmer in the 2000s although not immune to attacks, sometimes particularly brutal, against soldiers and civilians. These have mostly been attributed to (relatively rare) breakdowns in communication between returning civilian populations, the bodies facilitating return (the army, rural councils and local NGOs) and MFDC guerrillas operating in the area. However, more serious violence between the Senegalese army and MFDC guerrillas broke out in the border area in August 2009, eventually reaching the environs of Ziguinchor itself. By September the fighting prompted the displacement of hundreds of civilians, who sought refuge mostly in the town's interior. Many of those affected returned home after a few days or weeks but others took longer (IRIN 2010), despite the army eventually, in early 2010, dislodging the guerrilla elements concerned. These events were significant in that they caused the first new human displacement south of the Casamance River in over a decade, and underlined the death of the peace process as such. The run-up to presidential elections in Senegal in early 2012 again saw violence flare up across Ziguinchor region (IRIN 2012).

The extent to which the renewed violence of recent years may slow return to the Guinea-Bissau border zone is unclear. However, it seems unlikely that it will do so in the longer term, given the considerable momentum that has built up over the past decade, and that earlier occasional attacks in the area had little lasting effect. From a situation of protracted displacement in the 1990s, the 2000s saw an initially tentative but increasingly sustained dynamic of return, which still continues. 


\section{Return in the Border Zone}

Various dimensions of the return dynamic are now discussed in terms of the relational spaces produced. Considered first is how the reoccupation and exploitation by villagers of habitable and agricultural lands have had to cope with ongoing security concerns (risks of attack, robbery and landmines) as well as an overgrown landscape and wrecked infrastructure. Second, and related, how new patterns of land tenure are constructed and contested in the return setting. Third, how the relationship between rural and urban livelihoods is developing, a product of current strategies among returnees aimed at minimizing economic and security risks and of a longer history of rural-urban migration in the area. And fourth, how the spaces of village life are affected by social change, driven by an apparently younger demographic among returnees after years away.

\section{Security, insecurity and new patterns of settlement}

Return in the border zone has, like displacement, been characterized by complex dynamics operating across relatively confined areas. In 2001, the process saw a small but symbolically important start when IDPs displaced in 1997 from Kandialan Diola, a peripheral suburb of Ziguinchor, began to return there from their places of refuge in safer quarters of the town (Evans 2005). This process continued, with a 'return frontier' (Evans 2009: 514) moving outward into rural areas. Initially it covered other relatively secure settings along the western stretch of the Ziguinchor-Kolda road, which follows the south bank of the Casamance River, with return then extending southward to zones of previous large-scale displacement closer to the Guinea-Bissau border. The lead taken by particular displaced families or whole village communities was copied, and return accelerated. If given the opportunity, most IDPs in Ziguinchor or elsewhere in Casamance, and many refugees in neighbouring countries, are keen to quit the economic and social struggles of life in exile and return to their villages (Evans 2007). Again, it is difficult to quantify the scale of return to date but it has probably involved a few tens of thousands of displaced people (augmented by demographic growth in exile), with flows maybe peaking in the mid-2000s. In several 
cases observed it is notable that, as with their original flight, the majority of the village population has returned more or less together (Evans 2009).

The material landscape faced by returnees is daunting, however. Their villages have all but disappeared into dense forest regrowth. Infrastructure is absent or inadequate, and the local economy remains depressed because of ongoing insecurity, depopulation and difficulties in re-opening productive lands and marketing crops. In addition, landmines and guerrillas may still pose deadly hazards. Still, with generally reduced violence in the border zone, several multilateral and bilateral donors and international NGOs began funding reconstruction programmes in Casamance as the 2000s progressed. Some aid is channelled through government bodies and local NGOs, providing roofing materials and sometimes doors and shutters for houses rebuilt mainly by returnees themselves. Aid also funds construction of village amenities including wells, schools, clinics and community centres, as well as other infrastructure including roads, barrages to improve lowland rice cultivation, and farm tracks to facilitate marketing of produce. Yet contrary to the credit taken by the aid community, the return and reconstruction process is still primarily endogenous, with the drive and resources coming mostly from displaced communities themselves (Evans 2009). Aid usually follows rather than leads the process although it may still have important instrumental effects on political space.

Reconstruction and rehabilitation of the material landscape takes place amid a still-erratic and spatially uneven security environment, despite general improvements over the past decade or so. As in earlier, more difficult times, people's livelihood activities and problems - their relational economic space - reflect complex local articulations between insecurity and other factors including isolation and environmental and social change (Evans 2005). Two security issues stand out. The first is the ongoing risk of attack or robbery by MFDC guerrillas, as noted above. The second is the risk posed by landmines: in some cases, only villages and their immediate environs are swept for mines prior to return and reconstruction. Outlying areas, including productive lands such as orchards, are left pending more comprehensive demining efforts, although even state authorities now admit that the mine risk in the border zone looks to have been overestimated. ${ }^{4}$ Combined with effective 'mine education', this means 
that the average annual number of casualties has fallen to near-zero in recent years. Still, a few mine accidents have occurred around return villages during this period and concerns about mines, however exaggerated, understandably continue to define in part people's local space.

The effects of this security environment are most visible in changes in settlement layout in the border zone (Evans 2009). Typically, villages where the population was entirely displaced have adopted more compact shapes (compared with their pre-displacement forms) on return. This is in the interests of collective security against possible attack and to avoid perceived landmine risks in outlying areas. At least one village (Niabina) has been relocated over a short distance to put it more squarely on a road, again for security reasons. Consolidation has itself been a problematic process, both from the perspective of land tenure and, among certain ethnic groups, in changing long-standing habits of wide separation between houses. In a relational sense, this is not just a simple matter of settlement layout; it is about quotidian spatial activity, whether in interactions with neighbours or in valorizing (or not) agricultural land. Returnees to the village of Mandina Mancagne (close to Ziguinchor), for example, had previously lived in a more dispersed settlement style, where greater separation from their neighbours had allowed them to use surrounding land for toilet purposes. Now they have had to construct pit latrines for their new houses (Evans 2009). In villages where only part of the population was displaced, and in other relatively more secure settings, different dynamics can be observed. In certain villages, notably Boutoupa-Camaracounda, close to the border in an area heavily affected by the conflict, the opposite to consolidation is occurring. There is notable decompression of village cores in which the population took refuge during the worst of the violence, with people now moving back into previously abandoned peripheral quarters (Evans 2009).

A sense of liminality is also often evident in return villages in the spatial disjuncture, with economic consequences, between usable land and no-go areas (perceived or real). At Mpak, for example, farming activity around the new quarter to which people returned was at first severely constrained by a very real risk of landmines, with two mine-related deaths of returnees there. On a field visit in 2006, the cultivated area on the quarter's eastern edge stopped abruptly and the field beyond was overgrown; the 
orchards visible a short distance behind that were similarly inaccessible, much to the frustration of those seeking to derive a livelihood from them (Evans 2009).

In such contexts, where memories of former violence and ongoing insecurity still haunt the landscape, villagers often gain a sense of collective security from returning as a group. This reflects how the community has often maintained some measure of contact and cohesion even amid the dispersal and stresses of exile. Returnees are sometimes further emboldened by courageous village leadership and moral support from other social structures and mechanisms, including their families and youth associations. Not all the villages studied have shown such solidarities, however, and while in this 'postconflict' setting people are reluctant to talk about intra-community division, making it difficult to research, it is evident on the ground. Divisions in communities engendered by the conflict itself may create spatial separation on return. The village of Bambadinka, a significant battleground during the 1990s, is noteworthy for the way in which groups of returnees seem to have sought distance from each other and, in some cases, from the army camp there. Disagreements over resources for reconstruction are also sometimes reflected in how people live apart in the return setting. In all these cases, security dynamics (broadly defined) inform the physical shape of settlements and productive lands, which are in turn intimately tied to the relational spaces of economic and social activity.

\section{Land tenure regimes and wrangles}

Land tenure is also crucial in the return process. Land disputes, while not the root cause of the conflict, formed a major locus for unrest preceding the outbreak of the rebellion in 1982. With this history and amid growing rancorous land disputes across Senegal today, tenure remains an acutely sensitive matter in Casamance. Echoing concerns expressed by the humanitarian community elsewhere, resolving such issues is regarded as key to peacebuilding (IRIN 2008; Pantuliano 2009). Land disputes are most visible in urban and peri-urban areas of Casamance. The outskirts of Ziguinchor, particularly Kandialan, have proved a contentious area as people return, partly because of already-acute competition for farming land 
in the relatively secure environment provided by the town (Evans 2007) and the livelihood opportunities such spaces offer through 'commuting'.

In the rural setting of the border zone, too, land tenure often proves problematic. In situations where villages were formerly displaced in their entirety and people have now largely returned to their original holdings, or where there have been few supply constraints on customary authorities granting alternative plots to returnees, few problems seem to have arisen. By contrast, cases of village consolidation have necessitated considerable reorganization of holdings. A common pattern observed is where returnees with original holdings in central parts of a village cede plots to those who lived on the outskirts: because outlying areas cannot be accessed due to landmines or are otherwise deemed insecure, the latter group now needs to construct homes in the centre. This is in practice a challenging scenario: in Mandina Mancagne, for example, the resulting disputes nearly derailed the whole return process and only firm leadership kept it on track (Evans 2009). In villages where only some of the population fled, further problems have arisen where returnees have found that, in their absence, their holdings have been reallocated by the chieftaincy to other villagers or outsiders (Evans 2009). In rarer cases, people seem less attached to their land. The displaced inhabitants of the village of Saliot, in the Balantacounda area of the border zone of Sédhiou region, are mostly ensconced in their refuges in the nearby town of Djibanar. The Saliot leadership, at least, has no wish to return and indeed has asked for land to be granted to the villagers nearby, from the town's holdings. ${ }^{5}$ This reflects a historically shallow association with their original village, the land for which was only given to them in the 1940s, also by the leadership of Djibanar.

Land tenure thus remains a source of local tensions for returnees and again shapes their economic and social spaces: where and how they use their habitable and productive lands. These are not merely technical problems but concern much deeper psychological and social issues and their economic and spatial dimensions. This is relational space writ large by the dynamics of community, history and memory (Massey 2005). 


\section{Hedging their bets: evolving urban-rural linkages}

Other changes in relational space appear in the evolving urban-rural linkages of the return setting. Many returnees keep footholds both in their places of refuge and their home villages, sometimes to maintain ongoing livelihood activities in the former while trying to reconstruct their houses and restart agricultural activities in the latter. In other cases security informs such behaviour: while hoping for continued improvement, returnees are ready for possible deterioration, too. This is evinced by the curious sight of numbers of newly reconstructed but largely unused houses in some return villages (Evans 2009).

Given that very few returnees have their own transport (except maybe bicycles), distance is important in shaping the spaces of such relationships. Where the place of refuge is relatively close to the village of origin, some of the displaced can 'commute', walking to former homes and productive lands by day but returning to safety by nightfall - a widely observed phenomenon in Casamance (Evans 2003b, 2005) as in other situations of insecurity (for example Dunn 2007). This is particularly evident where IDPs are returning to peripheral quarters from village cores, or to villages from nearby urban centres such as Ziguinchor. In relational terms, 'commuting' means that use of space is subject to particular (usually diurnal) temporalities, again with economic consequences. In earlier fieldwork in BoutoupaCamaracounda, when it was one of the only villages left occupied in its rural community, use of agricultural land was paradoxically restricted by the presence of the army camp, as soldiers imposed a dusk-to-dawn curfew in the surrounding area. This limited access time to fields and orchards, particularly for the displaced former residents of an outlying quarter, now living in the village centre but still 'commuting' to their lands about two kilometres away during the day. The curfew made it impossible, for example, for farmers to maintain surveillance at times when monkeys were likely to eat crops (Evans 2005). The 'path space' (Barrett 2009) for 'commuters' may itself be insecure, with their journeys entailing risks of unwanted encounters with rebels, soldiers or bandits. Still, this does not prevent some from taking economic advantage of the return setting: in several return villages, even where people are only just starting to 'commute' to open up their lands, the resulting short-term bonanzas of firewood and 
charcoal are being taken to urban markets by whatever means available (often bicycles again, or handpulled carts) as an opportunistic livelihood activity (Evans 2009).

The situation is different in more rural areas of the border zone, further from any town and where typically several neighbouring villages have been wholly emptied and little is left standing of any of them. Under circumstances where distance renders 'commuting' difficult or to give themselves more cover, time and energy during reconstruction, some returnees construct temporary shelters of wood and leaves, although in a few villages more substantive structures have been provided as part of international aid projects. Returnees visit and even sleep in these so that they can start clearing and revalorizing their lands and rebuilding their houses, despite poor living conditions. Those sleeping in shelters are exposed to the elements, insects and snakes, and the supply of food and water is problematic.

But the longer-term question of how returnees navigate the relationship between town and village life encompasses more than these immediate concerns of security, livelihoods and house construction. It relates to deeper issues, long-rehearsed in African Studies, about the more fundamental economic and social relationship between the urban and the rural, and what this means for people's sense of 'home' (Mercer et al. 2008). Many of the displaced have a deep-seated sense of affection and belonging in relation to their home villages, perhaps enhanced through years of exile, often in economically and socially desperate circumstances. Yet like many from Casamance, with its history of economic migration to Dakar and other urban centres in northern Senegal and The Gambia, returnees continue to live with the social contradictions and tensions created by longer-distance rural-urban linkages (Foucher 2002; Lambert 2002). Such relationality has long been conceptualized through understandings of multilocal households, with family members dispersed across space but still functioning to some extent within one social unit (Murray 1981). This in turn problematizes the notion of 'displacement' as being a function of conflict alone, or as a one-off occurrence: at the time of such an event (specifically the physical dislocation of people and loss of their houses, lands and other property), many 'villagers' may not have been at home anyway (Evans 2007) and may continue to be absent, as outmigrants, from the return setting in the interests of making a living. 'Displacement' as defined here is thus not happening in isolation, as an 
aberration in an otherwise sedentary and stable life for those affected. Rather it is situated in more complex, multi-layered spaces of mobility, and immobility.

\section{Demographic change and youth opportunity}

A related issue is demographic change amid displacement and return. It is widely claimed among the displaced that a significant number of older people have died prematurely because of the original displacement event itself or, more commonly, the stresses of exile (Evans 2003b). This is a difficult claim to test, however. Numerous cases of deaths of displaced elders are certainly cited, and the returning population is predominantly a young one, creating pressures on the provision of school services in the reconstruction process in the border zone (Evans 2009). But this must be situated in a demographic context (for Senegal and sub-Saharan Africa more generally) of relatively early death in general and a burgeoning youth population. The UNDP (2013) gives average life expectancy at birth in Senegal at only 59.6 years, while the 2002 national census put $54.9 \%$ of the population at less than 20 years old (République du Sénégal 2006). Analytically isolating a 'mortality crisis' due to displacement is therefore hard, although this is not to deny that premature deaths may well have occurred.

Whatever the true demographic situation, the role of youth in the return and reconstruction process is crucial. 'Youth', in Casamance as elsewhere in Africa, is a socially constructed category related not just to biological age but to factors such as marital status, initiation, residency and economic dependency/independence. The picture is complex and fluid, therefore. In Lower Casamance, for example, men typically begin to marry in their mid-30s (women considerably younger) but in some cases they may still be defined as youth (jeunes) for some years while they establish their own households (Evans 2003b). For the purposes of discussion, the term is here used more inductively, in the sense of members of near-ubiquitous village youth associations, which show various degrees of organization, whether formally registered or not. In some villages, youth have been the main drivers of return, partly to help their parents escape the difficult situations of exile, perhaps partly to avoid those situations themselves as they grow up. At times they are certainly also trying to access the benefits of international 
aid but, while such external forces may be influential (as in other post-conflict settings; see Fanthorpe \& Maconachie 2010), interviews also point to the sincere desire of youth to help their communities rebuild. In a context of widespread youth under- and unemployment, a desire for funded development projects and livelihoods is anyway legitimate enough. With only their own resources, youth associations have mobilized to help return through work parties - for example clearing bush and building houses - and through lobbying the authorities for other support (official approvals, security and logistics).

Yet returning youth populations themselves face particular challenges. Those who fled as children with their parents, or who were born in exile and grew up in town, sometimes struggle in returning to a village that they never knew or scarcely remember, and are reluctant to abandon urban life and amenities. The relationship of youth with the spaces of return is thus different from that of their parents, and their aspirations can reflect this. The need for social activity is evinced in some return villages by the efforts that youth put into carving football pitches out of dense forest regrowth or desires, expressed in interviews, for the construction of youth centres. Such activity is not trivial. The social space of the border zone has been fragmented by displacement: depopulation, isolation of remaining and returning villages, overgrown roads and in some cases continuing security concerns all serve to disconnect communities from each other and reduce opportunities for social as well as economic engagement. Even the local NGO Enfance et Paix, whose projects support children and youth, speaks in terms echoing Schmitz (1994) of zones 'destructurées' by the conflict: a word suggesting social destabilization and break-up as well as physical loss of infrastructure and services. ${ }^{6}$ In this setting, intervillage football tournaments and dances, for example, help form linkages and mobility between youth groups of different villages. This in turn rebuilds confidence, breaking out of Oslender's (2008) 'spaces of confinement', and may lay foundations for future economic and political relationships across the zone. As well as keeping youth entertained and thereby engaged with wider village life, social interaction can help remake relational space across the border zone as it repopulates. 


\section{The Remaking of Political Space and its Discontents}

The chapter now addresses another important dynamic related to the return process in Casamance, namely the remaking of local political space and boundaries. The political and the economic interlink closely and the politico-spatial changes discussed here have material consequences in the border zone. These changes take different forms at different levels and in some cases are subtle and not immediately visible. In some places, they directly reflect new administrative divisions. Elsewhere, instances are found where the relational spaces of real economic, social and political life in the context of displacement do not fit tidily into normative administrative territory, or bear little practical relation to it, or are even in conflict with it. The drivers for reconfigurations of political space are similarly complex. In some cases, long-term political projects underlie this process of remaking. In others, political entrepreneurs (in the sense of creative individuals who broker development and other projects with a mixture of political and economic goals; see Hüsken 2010) seek to take advantage of opportunities provided by return, reconstruction and international aid to reshape space in their favour.

At village level, a striking example of such a process is seen in Mpak, south of Ziguinchor on the Guinea-Bissau border (Evans 2009). The village population was partially displaced and those concerned mostly living as refugees in Guinea-Bissau - returned to a new, consolidated quarter bringing together people from two formerly displaced ones. Reconstruction, while ultimately successful, was blighted by jealousies and resentment from those who had stayed put in the rump of the village, with little support, against those now coming back with the benefits of international aid. But at local political level, the main issue was that the return quarter established itself as a largely autonomous unit and accessed aid directly, without passing through the village chieftaincy. This quarter gives the strong impression of a village apart. It is geographically separate from the rump of the village and about a kilometre away from the main village square. It manages its own affairs and has direct relationships with NGOs bringing development projects. While the chief of Mpak and some local NGOs involved with the original return project have 
tried, in interviews, to downplay this autonomy, it is noteworthy that in local government circles in Ziguinchor, the return quarter is spoken of quite openly as a separate village, not as part of Mpak.

Further reconfiguration of local polities is found further east, in the Balantacounda area. ${ }^{7}$ To understand this process, the original division of Casamance, in 1984, needs to be revisited. This was widely seen as gerrymandering by then-President Abdou Diouf in an attempt to 'isolate' the rebellion in its western epicentre, from where the majority of MFDC membership - mainly of the Diola ethnic group - was derived; and to undermine separatist claims to whole-Casamance nationalism. Lower Casamance became Ziguinchor region, while Middle and Upper Casamance became Kolda region. Middle Casamance thus remained a neglected space, affected badly by violence at times from the mid-1990s onwards (Evans 2004) but falling outside of the area in which the conflict has been more formally recognized and managed, and to which reconstruction aid has therefore more recently been given. Middle Casamance also remained as one department, Sédhiou, named for its chief town, lying on the north bank of the Casamance River. For people in the Balantacounda and elsewhere in the Guinea-Bissau border zone of the department, this made access to their departmental capital difficult as it involved crossing the River, wide and treacherous in these middle reaches. Many preferred to go to Ziguinchor, more easily accessible via public transport even on the badly degraded main road and much closer than their own regional capital (Kolda). For purposes of public administration, the relational spaces of Balantacounda inhabitants simply did not fit formal political territory.

Becoming a department in its own right was therefore a long-standing political project for the Balantacounda, to give better access to state services and resources and to recognize the area's particular identity. The call for this new department was also possibly driven by the stresses of the conflict, particularly those placed on its largest town, Goudomp. Fieldwork in 2001 found the town cramped and under-resourced for its population, which was swollen with IDPs (Evans 2003b). In 2008, the Balantacounda achieved its long-desired status when Sédhiou department became a region in its own right, between Ziguinchor region and (the now reduced) Kolda region. Within Sédhiou region, new departments were created including that of Goudomp, effectively a department of the Balantacounda. 
This was an evident source of pride to the people of Sédhiou town ${ }^{8}$ while Goudomp is slowly upgrading its administrative and commercial services in line with its new status as departmental capital. Rural communities in the Balantacounda were also reconfigured, with one rural council's seat moved from Diattacounda - now given urban municipality status - to Simbandi Balante. Rural dwellers in the Balantacounda seem largely pleased with this arrangement as it greatly improves their access to state services south of the River, in Goudomp, Simbandi Balante and nearby Djibanar (the latter is the seat of another rural community). There is also a feeling that local identity - a sense of the Balantacounda as a distinct space - is better recognized.

Not everyone likes the new administrative set-up, however. In Safane, a village in the interior of the Balantacounda, the leadership feels affronted by the move of the seat of their rural community from Diattacounda to Simbandi Balante, on the main Ziguinchor-Kolda road, and not to their village. This is partly rooted in Safane's perceived historical right to this status because it was, in colonial times, a centre of French governance. This is also an unusually well-educated, organized and connected village for the Balantacounda. It has managed to access international aid projects, still sparse in the area, and plans to build a secondary school with support from its hometown association in Paris. But its ambitions to be the seat of the rural community were never going to be realized. Experiences further west in Ziguinchor region, where such seats have been attacked and staff displaced (Evans 2005), should be acknowledged. As noted above, the village of Boutoupa-Camaracounda, close to the border, is still under army protection and the president of its rural council remains in exile in Ziguinchor, although administrative business is increasingly moving back to the village. In the Balantacounda, moving the seat of a rural community from the main road down to Safane, on the edge of a large forest on the Guinea-Bissau border - regardless of the village's strong identity and sense of manifest destiny - would be risky. However implicitly, the relational spaces of insecurity in the border zone still inform the map of administrative territory.

Other political discontents include those in the MFDC, which contests the new administrative divisions more widely. Separatists more generally point to and play on the extent to which the territorial limits and administrative status of Casamance and political units within it have always been mired in 
controversy (Diatta 2008). Elements of the MFDC political wing ${ }^{9}$ complained that the new Sédhiou region was further 'balkanization' of Casamance, seeing it as another attempt to wipe the name 'Casamance' from the map and stymie construction of a Casamance national identity. This is perhaps ironic in that, for the MFDC, its own constituency has tended to be a greater problem than the administrative map as such: it has always struggled to escape from being labelled as a predominantly Lower Casamance, Diola movement. But the contestation here represents a further case of how reconfiguration of administrative territory clashes with the separatists' very different understanding of political space, including the historical status of Casamance itself.

The role of global forces in relation to these new administrative divisions is also ambiguous, as these forces may in turn be instrumentalized by local interests for material benefit. In the case of Sédhiou region, another benefit (if not necessarily a driver) of the new administrative set-up may be coopération decentralisée (decentralized development aid). In certain Western European countries such as France, Spain and Italy, some bilateral aid has been devolved from central government, with regional and sometimes other layers of their local government system giving aid directly to regional and local governments in developing countries. This is quite visible in Casamance and the ability to access such aid, as well as state resources in general, puts a further premium on a territory being defined as a region or department, a point exploited by political entrepreneurs. One of the architects of Sédhiou region ${ }^{10}$ notes that its status provides the juridical basis for it now to canvass for decentralized aid.

The situations considered show how new political spaces may be shaped by relationships at various scales, domestic and external. At Mpak, a new village has been created not by official statute but through a remaking of political structures under the combined influence of local ambition and international aid. It shows how a relational construction of space clashes with normative administrative territory but (in this case) reflects local reality more closely and has clear material consequences. In Middle Casamance, meanwhile, a different process is occurring as administrative territory is being more closely aligned with the realities of relational space, but again with possible benefits from international aid. While Sédhiou region and Goudomp department may bring better access to domestic patronage and 
external resources, it is important nonetheless to add that recognition of such political spaces in itself has profound symbolic value, especially in a long-neglected area like this.

\section{Conclusion}

The lens of relational space (as concept) shows how the Guinea-Bissau border zone of Casamance is constantly being remade. The area is characterized by fewer if more densely populated settlements than before, and poorer social linkages between and sometimes within them. In addition, it exhibits undervalorization of productive resources and patchy political engagement at all levels with and within returning populations. Yet in other ways the situation of returnees shows continuities with the past. In simple physical space, it is mostly existing village sites, fields and orchards that are being opened up by communities that have maintained some social cohesion even during exile. The ongoing adaptability that returnees show in resuming old economic activities and taking up new ones also represents more of a continuum than a break with their previous states, during exile as well as before displacement (Evans 2009). While such activities often occur amid particularly tight constraints in the border zone today, rural livelihoods were never easy and people have to show the same resourcefulness as before.

The border zone furthermore illustrates how contestations, both violent and non-violent, shape space itself, rather than space being a neutral vessel in which they happen. The ever-shifting landscapes of economic, social and political communities observed, and the complexities and ambiguities of history and memory, figure here as they do in other situations of displacement. This messiness and eternal incompleteness is, as Massey (2005) explains, in the very nature of relational space. The case explored also shows the relationships between normative perspectives on displacement and local understandings. Even the large displacement flows that catch the attention of international agencies are still the product of complex articulations between people, their resources (material and social), and the broader context (Lindley 2009) - in Massey's terms again, the sum of many, local 'stories-so-far'. The overlaps and mismatches between real, dynamic, lived space and normative political territory are also highlighted here, 
as they are elsewhere (Retaillé \& Walther 2011), when such situations are considered in relational terms. A logic of access to external resources, including state and international aid, may in turn shape political and economic space, from regional down to very local level, as the cases of Sédhiou region and Mpak respectively show. Relationality - stepping outside of the fixed box of physical space - helps us to understand the linkages between the local and the global in these contexts. However, the analysis here shows how the local must also be understood in its own terms, for example, in the sense of local identity seen in the Balantacounda; global forces do not explain everything.

The displacement economies of the area thus reflect complex tensions between fragmentation and new solidarities, and between rupture with the past and evident continuities. They represent an everunfolding response to political and social crisis, clearly linked to the Casamance conflict but also not restricted to that dynamic alone, in space or time. And they demonstrate the importance of the local and the contingent: particular historical trajectories matter, as do individuals and their projects, whether courageous, visionary, entrepreneurial, self-serving or everyday. It is all these people's actions, as well as external forces, that continue to remake local space in Senegal's southern borderlands.

\section{References}

Barrett, M. (2009) 'The social significance of crossing state borders: home, mobility and life paths in the Angolan-Zambian borderland'. In Jansen, S. \& S. Löfving (eds) Struggles for Home: Violence, Hope and the Movement of People, pp. 85-108, Berghahn Books, Oxford.

Black, R. \& M. Sessay (1997) 'Forced migration, land-use change and political economy in the forest region of Guinea', African Affairs, Vol. 96, No. 385, pp. 587-605.

Black, R. \& M. Sessay (1998) 'Forced migration, natural resource use and environmental change: the case of the Senegal River Valley', International Journal of Population Geography, Vol. 4, No. 1, pp. $31-47$. 
Diatta, O. (2008) La Casamance : essai sur le destin tumultueux d'une région, Harmattan, Paris.

Dunn, K.C. (2007) 'Uganda: the Lord's Resistance Army’. In Bøås, M. \& K.C. Dunn (eds) African Guerrillas: Raging Against the Machine, pp. 131-149, Lynne Rienner, London.

Engel, U. \& P. Nugent (eds) (2010a) Respacing Africa, Brill, Leiden.

Engel, U. \& P. Nugent (2010b) 'Introduction: the spatial turn in African Studies'. In Engel, U. \& P. Nugent (eds) Respacing Africa, pp. 1-9, Brill, Leiden.

Englund, H. (1996) 'Waiting for the Portuguese: nostalgia, exploitation and the meaning of land in the Malawi-Mozambique borderland', Journal of Contemporary African Studies, Vol. 14, No. 2, pp. 157172.

Englund, H. (1999) 'The self in self-interest: land, labour and temporalities in Malawi's agrarian change', Africa, Vol. 69, No. 1, pp.139-159.

Evans, M. (2003a) 'Ni paix ni guerre: the political economy of low-level conflict in the Casamance'. In Collinson, S. (ed.) Power, Livelihoods and Conflict: Case Studies in Political Economy Analysis for Humanitarian Action, Humanitarian Policy Group Report, No. 13, pp. 37-52, Overseas Development Institute, London.

Evans, M. (2003b) ‘The Casamance, Senegal: ‘war economy’ or business as usual?', Unpublished PhD thesis, University of London (King's College London).

Evans, M. (2004) Senegal: Mouvement des forces démocratiques de la Casamance (MFDC), Africa Programme Armed Non-State Actors Project Briefing Paper, No. 2, Chatham House, London.

Evans, M. (2005) 'Insecurity or isolation? Natural resources and livelihoods in Lower Casamance', Canadian Journal of African Studies, Vol. 39, No. 2, pp. 282-312.

Evans, M. (2007) “"The suffering is too great”: urban internally displaced persons in the Casamance conflict, Senegal', Journal of Refugee Studies, Vol. 20, No. 1, pp. 60-85.

Evans, M. (2009) 'Flexibility in return, reconstruction and livelihoods in displaced villages in Casamance, Senegal', GeoJournal, Vol. 74, No. 6, pp. 507-524. 
Evans, M. (2010) 'Primary patriotism, shifting identity: hometown associations in Manyu division, South West Cameroon', Africa, Vol. 80, No. 3, pp. 397-425.

Evans, M. \& Ray, C. (2013) 'Uncertain ground: The Gambia and the Casamance conflict'. In Saine, A., E. Ceesay \& E. Sall (eds) State and Society in The Gambia since Independence, pp. 247-287, Africa World Press, Trenton NJ.

Fanthorpe, R. \& R. Maconachie (2010) 'Beyond the "crisis of youth"? Mining, farming, and civil society in post-war Sierra Leone', African Affairs, Vol. 109, No. 435, pp. 251-272.

Foucher, V. (2002) 'Les « évolués », la migration, l'école: pour une nouvelle interprétation de la naissance du nationalisme casamançais'. In Diop, M.C. (ed.) Le Sénégal Contemporain, pp. 375-424, Karthala, Paris.

Foucher, V. (2007) 'The resilient weakness of Casamançais separatists'. In Bøås, M. \& K.C. Dunn (eds) African Guerrillas: Raging Against the Machine, pp. 171-197, Lynne Rienner, London.

Gale, L.A. (2006) 'Sustaining relationships across borders: gendered livelihoods and mobility among Sierra Leonean refugees', Refugee Survey Quarterly, Vol. 25, No. 2, pp. 69-80.

Harvey, D. (2005) 'Space as a keyword'. In Castree, N. \& D. Gregory (eds) David Harvey: A Critical Reader, pp. 270-293, Blackwell, Oxford.

Howard, A.M. (2010) 'Actors, places, regions, and global forces: an essay on the spatial history of Africa since 1700’. In Engel, U. \& P. Nugent (eds) Respacing Africa, pp. 11-44, Brill, Leiden.

Hüsken, T. (2010) 'The neo-tribal competitive order in the borderland of Libya and Egypt'. In Engel, U. \& P. Nugent (eds) Respacing Africa, pp. 170-205, Brill, Leiden.

IRIN (2008) 'Finding incentives for peace in Casamance', Integrated Regional Information Networks, United Nations Agency for the Coordination of Humanitarian Affairs, 25 June 2008. Online at http://www.irinnews.org/Report.aspx?ReportId=78944. 
IRIN (2009) 'Analysis: Closer to war than to peace in Casamance?', Integrated Regional Information Networks, United Nations Agency for the Coordination of Humanitarian Affairs, 18 September 2009. Online at http://www.irinnews.org/Report.aspx?ReportId=86217.

IRIN (2010) 'Ousmane Goudiaby, "Even if one is afraid, one has no choice”, Integrated Regional Information Networks, United Nations Agency for the Coordination of Humanitarian Affairs, 3 February 2010. Online at http://www.irinnews.org/HOVReport.aspx?ReportId=87984.

IRIN (2012) 'No end in sight to Casamance conflict', Integrated Regional Information Networks, United Nations Agency for the Coordination of Humanitarian Affairs, 17 February 2012. Online at http://www.irinnews.org/Report.aspx?ReportId=94895.

Kelsall, T. \& Mercer, C. (2003) 'Empowering people? World Vision \& “transformatory development” in Tanzania', Review of African Political Economy, Vol. 30, No. 96, pp. 293-304.

Lambert, M.C. (2002) Longing for exile: migration and the making of a translocal community in Senegal, West Africa, Heinemann, Portsmouth NH.

Leach, M. (1992) Dealing with displacement: refugee-host relations, food and forest resources in Sierra Leonean Mende communities during the Liberian influx, 1990-91, Institute of Development Studies, Brighton.

Lindley, A. (2009) Leaving Mogadishu: the war on terror and displacement dynamics in the Somali regions, MICROCON Research Working Paper, No. 15, A Micro Level Analysis of Violent Conflict, Institute of Development Studies, Brighton.

Massey, D. (2005) For Space, Sage, London.

McGregor, J. (1997) Staking their claims: land disputes in southern Mozambique, Land Tenure Center Paper, No. 158, University of Wisconsin, Madison WI.

McGregor, J. (1998) 'Violence and social change in a border economy: war in the Maputo hinterland, 1984-1992', Journal of Southern African Studies Vol. 24, No. 1, pp. 37-60. 
Mercer, C. (2002) 'Deconstructing development: the discourse of maendeleo and the politics of women's participation on Mount Kilimanjaro', Development and Change, Vol. 33, No. 1, pp. 101-127.

Mercer, C., B. Page \& M. Evans (2008) Development and the African diaspora: place and the politics of home, Zed Books, London.

Murray, C. (1981) Families divided: the impact of migrant labour in Lesotho, Cambridge University Press, Cambridge.

Oslender, U. (2008) 'Another history of violence: the production of "geographies of terror" in Colombia's Pacific Coast Region', Latin American Perspectives, Vol. 35, No. 5, pp. 77-102.

Pantuliano, S. (ed.) (2009) Uncharted territory: land, conflict and humanitarian action, Practical Action, Rugby in association with Overseas Development Institute, London.

République du Sénégal (2006) Résultats du troisième recensement général de la population et de l’habitat du Sénégal (RGPHIII) 2002: rapport national de présentation, Agence Nationale de la Statistique et de la Démographie, Dakar.

Retaillé, D. \& O. Walther (2011) 'Spaces of uncertainty: a model of mobile space in the Sahel', Singapore Journal of Tropical Geography, Vol. 32, No. 1, pp. 85-101.

Schmitz, J. (1994) 'Cités noires: les républiques villageoises du Fuuta Tooro (Vallée du fleuve Sénégal)', Cahiers d'Études africaines, Vol. 133-135, No. XXXIV-1-3, pp. 419-460.

UNDP (2013) Human Development Report 2013. The rise of the south: human progress in a diverse world, United Nations Development Programme, New York NY.

UNHCR (2011) Global trends 2010, United Nations High Commissioner for Refugees, Geneva.

Unruh, J.D. (1998) 'Land tenure and identity change in postwar Mozambique’, GeoJournal, Vol. 46, No. 2, pp. 89-100.

Unruh, J.D. \& J. Bailey (2009) 'Management of spatially extensive natural resources in postwar contexts: working with the peace process', GeoJournal, Vol. 74, No. 2, pp. 159-173. 
Unruh, J.D., N.C. Heynen \& P. Hossler (2003) 'The political ecology of recovery from armed conflict: the case of landmines in Mozambique', Political Geography, Vol. 22, No. 8, pp. 841-862.

van den Bersselaar, D. (2005) 'Imagining home: migration and the Igbo village in colonial Nigeria'.

Journal of African History, Vol. 46, No. 1, pp. 51-73.

\footnotetext{
${ }^{1}$ The author warmly thanks the many Casamançais who participated in the research. Fieldwork would also not have been possible without the author's assistant, Oumar Badiane, and staff of the local NGO APRAN. The most recent phase of research was kindly funded by a Small Research Grant from the British Academy. The chapter has benefited greatly from feedback from participants at a writeshop at the Nordic Africa Institute, Uppsala, in 2009 and from further discussion at the Fourth European Conference on African Studies, also in Uppsala, in 2010. The insightful comments of the editor of this volume, Amanda Hammar, have been greatly valued throughout the writing process. The input of colleagues at the University of Chester, particularly Brenda Garvey and Chris Ribchester, and of Ben Page at University College London, are also gratefully acknowledged.

${ }^{2}$ Following the French model, a department is an administrative division within a region.

${ }^{3}$ An administrative division comprising a collection of neighbouring villages and run by a rural council.

${ }^{4}$ Interview with officer of national demining agency, Ziguinchor, 3 August 2009.

${ }^{5}$ Interview, Djibanar, 14 July 2009.

${ }^{6}$ Garvey, personal communication, 9 August 2010.

${ }^{7}$ Much of this discussion is based on interviews conducted during fieldwork in the Balantacounda in July 2009, unless otherwise indicated.

${ }^{8}$ Garvey (who was conducting fieldwork in Sédhiou town at the time), personal communication, 11 June 2009.

${ }^{9}$ Interview, Ziguinchor, 31 July 2009.

${ }^{10}$ Interview, Ziguinchor, 18 July 2010.
} 